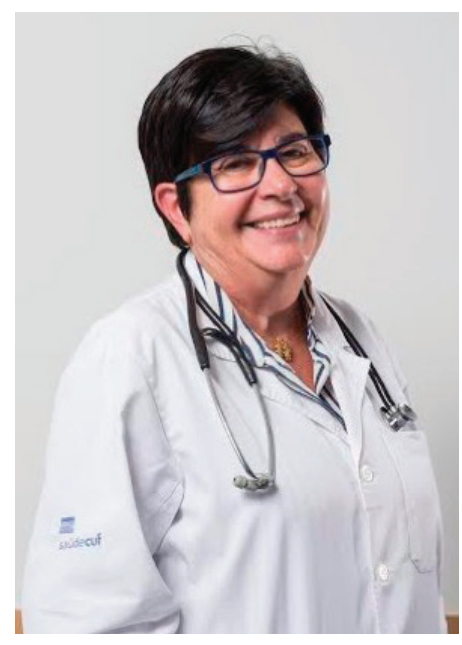

\title{
A Investigação Clínica e o Exercício da Profissão Médica
}

\section{Clinical Research and the Medical Profession Practice}

Bárbara Parente 1

É com o maior gosto, que participo em mais uma edição da revista científica do Grupo José de Mello Saúde - Gazeta Médica, desta vez fazendo o seu Editorial, na qualidade de Editor Associado da revista.

A reedição de uma Revista que teve a sua primeira edição há cerca de 70 anos (1948) e descontinuada 16 anos mais tarde em 1964, tendo emergido com a dinâmica que se reconhece nos seus três primeiros números, pressupõe-Ihe uma longa vida e uma enorme vitalidade, pelo seu já reconhecimento e desenvolvimento científico.

Os números até agora editados foram pautados pela multidisciplinaridade, rigor científico e inovação adaptada aos nossos dias, fazendo jus ao que de meIhor se produz em medicina.

O quarto número da revista apresenta-se mais uma vez duma forma multidisciplinar, quer na abordagem das várias áreas das ciências médico/cirúrgicas, quer no tipo de trabalho apresentado.

Assim ao abrirmos com chave de ouro, este número
Autor Correspondente: Bárbara Parente [barbara.parente@gmail.com]

da revista com o artigo de perspetiva "Saúde e Educação" da Prof. Maria Amélia Ferreira, Presidente da Faculdade de Medicina da Universidade do Porto, passando por artigos originais e de revisão de grande valor nos vários temas da Medicina atual, aos casos clínicos das várias especialidades, mostrando o trabalho do nosso dia-a-dia e finalizando com um tema histórico, fica-nos a expectativa de no futuro podermos ver incluídos também estudos prospetivos a serem efetuados no âmbito da nossa atividade de investigação clínica.

A atividade assistencial aos doentes, pilar de atuação do médico, conduz-nos muitas vezes a falta de tempo para escrever e registar adequadamente o nosso trabalho, atentos às inúmeras solicitações a que todos estamos diariamente sujeitos, mas não podemos abdicar da responsabilidade que cada um de nós tem na área da investigação clínica, fator muito importante no desenvolvimento das melhores terapêuticas e atitudes para os nossos doentes, podendo, por um lado rever a forma como os tratamos e 
por outro lado, oferecer-Ihes o que de melhor se faz no mundo científico.

Estou a falar exatamente sobre estudos de investigação clínica da iniciativa do investigador, académicos ou outros, considerando igualmente aqueles que têm a indústria como promotor.

Se alguns hospitais do grupo, nomeadamente o Hospital de Braga (com o centro clínico académico), apresentam já um amplo desenvolvimento nesta altura, ainda nos encontramos em período de grande desenvolvimento noutras unidades, não querendo deixar aqui de referir o esforço efetuado durante o ano em curso pela Academia CUF no desenvolvimento desta área de trabalho, inclusive com a implementação a tempo inteiro da figura do study coordinator em várias unidades do grupo, motor importante para um trabalho eficaz, responsável e cientificamente rigoroso.
Prevê-se para 2017 uma duplicação dos estudos, a fazer crer pelas várias parcerias e pelos múltiplos feasibilities em curso, esperando que estas e outras iniciativas, possam levar rapidamente à submissão, aceitação e publicação de trabalhos de investigação ou de revisão nas páginas da Gazeta Médica.

Contudo, há que louvar o muito que se tem feito (em pouco tempo), inclusivamente a publicação do livro "70 Anos/Excelência Clínica" e a edição para breve, do livro de "Casos Clínicos Multidisciplinares", que a somar à edição trimestral da Gazeta Médica constituem nesta data, já três importantes focos científicos.

Estas iniciativas são a expressão máxima da vontade duma equipa multidisciplinar motivada e coesa, para levar em frente uma obra científica igualmente importante, como tratar os doentes, que todos dias em nós confiem.

Contamos com todos para prosseguirmos! 